\title{
Data report: microbial activity determined by microcalorimetry and cultivation of bacteria from hydrothermally influenced subsurface marine sediments in the mid-Okinawa Trough (IODP Expedition 331) ${ }^{1}$
}

Axel Schippers, ${ }^{2}$ Anja Breuker, ${ }^{2}$ and Marco Blöthe ${ }^{2}$

\section{Chapter contents}

Abstract...................... 1

Introduction $\ldots \ldots \ldots \ldots \ldots \ldots \ldots \ldots 1$

Materials and methods ................

Results and conclusions............... 3

Acknowledgments.................4

References.................... 4

Tables........................... 5

'Schippers, A., Breuker, A., and Blöthe, M., 2016. Data report: microbial activity determined by microcalorimetry and cultivation of bacteria from hydrothermally influenced subsurface marine sediments in the mid-Okinawa Trough (IODP Expedition 331). In Takai, K., Mottl, M.J., Nielsen, S.H., and the Expedition 331 Scientists, Proceedings of the Integrated Ocean Drilling Program, 331: Tokyo (Integrated Ocean Drilling Program Management International, Inc.). doi:10.2204/iodp.proc.331.203.2016

${ }^{2}$ Federal Institute for Geosciences and Natural Resources (BGR), Stilleweg 2, 30655 Hannover, Germany. Correspondence author:

axel.schippers@bgr.de

\begin{abstract}
Using sediment samples from five Integrated Ocean Drilling Program Expedition 331 sites, bacteria were cultivated on different media, and microbial activity was measured by isothermal microcalorimetry at $25^{\circ}$ and at $90^{\circ} \mathrm{C}$ to study hydrothermal influence. The data showed considerable activity of thermophilic microorganisms at $90^{\circ} \mathrm{C}$, but at $25^{\circ} \mathrm{C}$ significant activity could only be detected for aerobic conditions. Enhanced microbial activity at $90^{\circ} \mathrm{C}$ was mirrored by the enrichment of thermophilic sulfate reducers in agreement with published geochemical data. Aerobic and anaerobic cultures we obtained from hydrothermally influenced, deeply buried marine sediments at $12^{\circ} \mathrm{C}$ were not significantly different from those of other cold and temperate deeply buried marine sediments.
\end{abstract}

\section{Introduction}

Subseafloor microbes beneath active hydrothermal vents, in the "subvent biosphere," are believed to live near the upper temperature limit for life on Earth. Hydrothermally influenced deeply buried marine sediments were sampled during Integrated Ocean Drilling Program (IODP) Expedition 331, Deep Hot Biosphere (see the "Expedition 331 summary" chapter [Expedition 331 Scientists, 2011a]).

Site C0013 is located $\sim 100 \mathrm{~m}$ east of the main hydrothermal mound chains of the Iheya North hydrothermal field. In Hole C0013C, the core liner melted, indicating a temperature $>82^{\circ} \mathrm{C}$ at 12.5 meters below seafloor (mbsf). Site C0014 is located $\sim 450 \mathrm{~m}$ east of the high-temperature vents and mounds, and the temperature exceeded $210^{\circ} \mathrm{C}$ at only $50 \mathrm{mbsf}$. The temperature gradient was roughly linear from 0 to $47 \mathrm{mbsf}$, increasing from the bottom water temperature of $4.5^{\circ}-145^{\circ} \mathrm{C}$ over that depth range, but it deviated greatly from this line at 0-9 and $47-50$ mbsf, where it was clearly affected by high-temperature fluid pooling or lateral flow. Site C0015, located on a hill $\sim 600 \mathrm{~m}$ northwest of the active vents, represents a potential migration path for hydrothermal fluid; however, hydrothermal alteration was absent in the cored interval. Site C0017 is located $1550 \mathrm{~m}$ east of the high-tempera- 
ture vents of the Iheya North hydrothermal field, in an area of low heat flow. The overall temperature profile was exponential and concave upward, which is consistent with downwelling of cold water, implying that this was an area of recharge to the hydrothermal system. A maximum temperature of $90^{\circ} \pm$ $5^{\circ} \mathrm{C}$ was measured at the bottom of the deepest hole (C0017D) at 151 mbsf (see the "Expedition 331 summary" chapter [Expedition 331 Scientists, 2011a]).

Temperature gradients decrease greatly with distance from the active vents, from $>7^{\circ} \mathrm{C} / \mathrm{m}$ at Site C0013 to $3^{\circ} \mathrm{C} / \mathrm{m}$ at Site $\mathrm{C} 0014$ and $0.6^{\circ} \mathrm{C} / \mathrm{m}$ at Site C0017. Site C0015 has a relatively low heat flow and a surficial temperature gradient of $\sim 1^{\circ} \mathrm{C} / \mathrm{m}$. At Sites C0013, C0014, and C0017, the relatively high, moderate, and low heat flow areas east of the Iheya North hydrothermal field were drilled to investigate subseafloor microbial habitats and communities. Broad gradients of physical and chemical variation, both laterally and vertically, that could be affected by mixing between discharging hydrothermal solutions and recharging ambient bottom seawater (see the "Expedition 331 summary" chapter [Expedition 331 Scientists, 2011a]) characterizes this habitat.

Sampling of the sediments was done while applying contamination tests (Yanagawa et al., 2013). Using molecular ecology approaches, the deep biosphere of these sediments was analyzed (Yanagawa et al., 2014). Here, cultivation of bacteria with different media was done following previous Ocean Drilling Program (ODP)/IODP approaches (Batzke et al., 2007), and microbial activity was measured by isothermal microcalorimetry. The latter allows the sensitive detection of heat output generated by the sum of chemical and biological reactions in a sample. A chloroform treatment to kill the microorganisms allows for differentiation between chemical and biological activity. The higher the heat output, the higher is the activity of a sample (Schippers et al., 1995; Braissant et al., 2010; Schippers and Bosecker, 2005). To study hydrothermal influence on activity, measurements were carried out at $25^{\circ} \mathrm{C}$ and $90^{\circ} \mathrm{C}$ for comparison.

\section{Materials and methods}

Overall, 120 sediment samples from 5 sites (C0013C0017) to a maximum depth of 110 mbsf were taken onboard the D/V Chikyu for microbiological research at the Federal Institute for Geosciences and Natural Resources (BGR). The samples were taken from the centermost part of the sediment cores under aseptic conditions in an anaerobic box, put in anaerobic bags, and sent to BGR at $2^{\circ}-8^{\circ} \mathrm{C}$ as previously described in the "Methods" chapter (Expedition 331 Scientists, 2011b; Shipboard Scientific Party, 2003) and stored at $8^{\circ} \mathrm{C}$ until use.

To determine microbial activity, the heat output in microwatts per gram for each sample from sites C0014, C0015, and C0017 was measured in an isothermal microcalorimeter (Thermal Activity Monitor Thermostat type 2277; Thermometric, Sweden) within 1 month after the expedition. A measurement lasted for 2-4 h until a stable value was obtained. After measuring the total heat output (microbial and chemical) in a $\sim 5 \mathrm{~g}$ sample at $25^{\circ}$ and $90^{\circ} \mathrm{C}$, the chemical heat output at $90^{\circ} \mathrm{C}$ was measured after chloroform treatment (addition of $0.5 \mathrm{~mL}$ chloroform and $24 \mathrm{~h}$ incubation and subsequent removal by vacuum evaporation) to kill the microorganisms, as described elsewhere (Schippers and Bosecker, 2005). Chemical heat output was only measured at $90^{\circ} \mathrm{C}$. Measurements under aerobic conditions were made in air; for anaerobic conditions, glass ampoules containing samples were closed in a nitrogen atmosphere (anaerobic box). Microbial substrates were not added for measurements. Activity values were calculated per sample dry weight (determined as weight difference after drying). Microbial activity can be calculated as the difference between total and chemical heat output (Schippers et al., 1995; Schippers and Bosecker, 2005).

For enrichment of microorganisms, liquid culture media were inoculated in a flow hood with sediment (Shipboard Scientific Party, 2003) from Sites C0013, C0014, and C0017 within 2 months after Expedition 331 . The media were based on artificial seawater as described by Batzke et al. (2007) and were amended either with a polymer or monomer solution. The polymer solution contained chitin, cellulose, and peptone at 0.5 per gram each, whereas the monomer solution contained 36 different carbon sources such as amino acids, fatty acids, organic acids, alcohols, and glucose (final concentration $=0.1 \mathrm{mM}$ ). Media for aerobic incubations were buffered with bicarbonate $/ \mathrm{CO}_{2}$. In media for anaerobic incubations, HEPES (2.38 per gram) was added, and $\mathrm{pH}$ was adjusted to 7.2-7.4 by addition of $\mathrm{NaOH}$ before autoclaving. After autoclaving, the media were cooled under $\mathrm{N}_{2}$ flow, and a solution of 10 vitamins (Balch et al., 1979 ) and sodium bicarbonate (0.2 per gram) were added from sterile stock solutions (Batzke et al., 2007). For the enrichment of sulfide-, manganese-, or iron-oxidizing bacteria, $1 \mathrm{~mL}$ of a $100 \mathrm{mM}$ sterilized filter and anoxic $(0.2 \mu \mathrm{m}) \mathrm{Na}_{2} \mathrm{~S}, \mathrm{MnSO}_{4}$, or $\mathrm{FeCl}_{2}$ 
solution was added in gradient tubes. The enrichment cultures were incubated at $12^{\circ}, 60^{\circ}, 70^{\circ}$, or $80^{\circ} \mathrm{C}$.

Growth was continuously checked by visual inspection (turbidity) and/or phase contrast microscopy, and in case of growth, colonies were picked and transferred to fresh media. Several aerobic and anaerobic enrichments were obtained. To identify isolates, 16S rRNA gene sequencing and analysis was done. The amplified polymerase chain reaction products of bacterial gene fragments were purified and sequenced at Microsynth sequencing company, Switzerland. Primers GM3F (5'AGAGTTTGATCMTGGC3') and GM4R (5'TACCTTGTTACGACTT3') were used for sequencing. The sequences obtained were edited with Geneious 6 software and compared with the NCBI database through BLAST searches.

\section{Results and conclusions}

The results for the microcalorimetric activity measurements of Expedition 331 samples are shown in Tables T1 and T2. Microbial activity can be calculated as the difference between total and chemical heat output. The data show considerable activity at $90^{\circ} \mathrm{C}$, which is partly attributed to microbial activity (50\% for aerobic conditions). At $25^{\circ} \mathrm{C}$, significant activity could only be detected for aerobic conditions. Overall, microcalorimetric measurements reveal activity of thermophilic microorganisms in the Expedition 331 samples.

Table T3 gives an overview of enrichment cultures and isolates; details are described in the following text. Overall, enhanced microbial activity at $90^{\circ} \mathrm{C}$ was mirrored by the enrichment of thermophilic sulfate reducers in agreement with geochemical data (Aoyama et al., 2014). The cultures we obtained from hydrothermally influenced, deeply buried marine sediments at $12^{\circ} \mathrm{C}$ were not significantly different from those of cold and temperate deeply buried marine sediments. We were not able to cultivate $A r$ chaea, for example, despite the fact that they are broadly found with 16S rRNA gene approaches (Yanagawa et al., 2014).

\section{Thermophiles}

The first attempts to cultivate thermophiles at $70^{\circ}$ and $80^{\circ} \mathrm{C}$ in liquid media under aerobic and anaerobic conditions with monomer or polymer solutions as a carbon source were unsuccessful; no growth was observed after 3 months of incubation. In a second enrichment attempt, incubation temperature was decreased to $60^{\circ} \mathrm{C}$ under anoxic conditions. Over an in- cubation period of 10 months, nearly all inoculated tubes showed activity by formation of black sulfide precipitation. We interpreted the formation of this precipitation as a sign of an ongoing sulfate reduction, because in control tubes with autoclaved or no inoculums, no formation of sulfide precipitation was observed. However, subculturing remained unsuccessful.

\section{Aerobic litho(hetero)trophs}

No (stable) sulfide- or iron-oxidizing enrichment culture at $12^{\circ} \mathrm{C}$ was obtained from the investigated depth intervals in the three cores. For microaerophilic Fe(II) oxidizers, only culture tubes inoculated with samples from Sites C0013 (0.2 and $0.3 \mathrm{mbsf}$ ), C0014 (2.1 mbsf), and C0017 (6.4 and 10.9 mbsf) showed a sharp band of Fe(III) precipitation, which indicates a microbially enhanced Fe(II) oxidation, in contrast to the fuzzy band in the chemical control tubes. Similar observations were made for the enriched aerobic sulfide oxidizers. None of these enrichment cultures could be successfully maintained. On the other hand, stable Mn(II)-oxidizing enrichment cultures were obtained from all core depth intervals. In all of these enrichment cultures, a sharp brown band $1-2 \mathrm{~cm}$ beneath the top of the agar in the gradient tubes developed over 3-4 weeks. In the chemical controls, only a weak and fuzzy band was observed. These putative Mn(II)-oxidizing bacteria could successfully be transferred to agar plates with the polymer mix as the carbon and energy source. The $16 \mathrm{~S}$ rRNA gene of five isolates was partially sequenced (320-430 bp), and the isolates were affiliated to Bacillus oceani (91\%), whereas two isolates were affiliated to Bacillus aquimaris (92\%). The obtained Mn(II)-oxidizing cultures could grow on agar plates in the presence of $5 \mathrm{mM} \mathrm{Mn}$ (II) but without an additional carbon source.

\section{Aerobe and anaerobe heterotrophic mesophiles}

Aerobe heterotrophic mesophiles were successfully cultivated from all samples at $12^{\circ} \mathrm{C}$ with monomer and polymer as the carbon source on agar plates. From Site C0013, two isolates were obtained affiliated to Halobacillus litoralis (92\%) and one to Bacillus niacini (95\%); both are species originally isolated from deep-sea samples. Two additional isolates from Site C0013 are affiliated to Marinobacter salsuginis (90\%) and Marinobacter hydrocarbonoclasticus (93\%). From Hole C0017, we obtained two isolates affiliated to Shewanella benthica (89\%), three isolates affiliated to Cytophaga fermentans (92\%), and one isolate affili- 
ated to Idiomarina spp. (92\%) and Psychrobacter spp. $(95 \%)$. None of the obtained isolates could grow at $60^{\circ} \mathrm{C}$.

\section{Acknowledgments}

This research used samples and data provided by the Integrated Ocean Drilling Program (IODP). This work is supported by the German Research Foundation (DFG) priority Program 527 IODP/ODP Grant SCHI 535/12 to A.Schippers.

\section{References}

Aoyama, S., Nishizawa, M., Takai, K., and Ueno, Y., 2014. Microbial sulfate reduction within the Iheya North subseafloor hydrothermal system constrained by quadruple sulfur isotopes. Earth and Planetary Science Letters, 398:113-126. http://dx.doi.org/10.1016/ j.epsl.2014.04.039

Balch, W.E., Fox, G.E., Magrum, L.J., Woese, C.R., and Wolfe, R.S., 1979. Methanogens: reevaluation of a unique biological group. Microbiological Reviews, 43(2):260-296. http://mmbr.asm.org/content/43/2/ 260.full.pdf + html

Batzke, A., Engelen, B., Sass, H., and Cypionka, H., 2007. Phylogenetic and physiological diversity of cultured deep-biosphere bacteria from equatorial Pacific Ocean and Peru margin sediments. Geomicrobiology Journal, 24(3-4):261-273. http://dx.doi.org/10.1080/ 01490450701456453

Braissant, O., Wirz, D., Göpfert, B., and Daniels, A.U., 2010. Use of isothermal microcalorimetry to monitor microbial activities. FEMS Microbiology Letters, 303(1):18. http://dx.doi.org/10.1111/j.15746968.2009.01819.x

Expedition 331 Scientists, 2011a. Expedition 331 summary. In Takai, K., Mottl, M.J., Nielsen, S.H., and the Expedition 331 Scientists, Proceedings of the Integrated Ocean Drilling Program, 331: Tokyo (Integrated Ocean Drilling Program Management International, Inc.). http://dx.doi.org/10.2204/iodp.proc.331.101.2011
Expedition 331 Scientists, 2011b. Methods. In Takai, K., Mottl, M.J., Nielsen, S.H., and the Expedition 331 Scientists, Proceedings of the Integrated Ocean Drilling Program, 331: Tokyo (Integrated Ocean Drilling Program Management International, Inc.). http://dx.doi.org/10.2204/ iodp.proc.331.102.2011

Schippers, A., and Bosecker, K., 2005. Bioleaching: analysis of microbial communities dissolving metal sulfides. In Barredo, J.-L. (Ed.), Methods in Biotechnology (Vol. 18): Microbial Processes and Products: Totowa, NJ (Humana Press Inc.), 405-412. http://dx.doi.org/10.1385/159259-847-1:405

Schippers, A., Hallmann, R., Wentzien, S., and Sand, W., 1995. Microbial diversity in uranium mine waste heaps. Applied and Environmental Microbiology, 61(8):29302935. http://aem.asm.org/content/61/8/ 2930.abstract

Shipboard Scientific Party, 2003. Explanatory notes. In D’Hondt, S.L., Jørgensen, B.B., Miller, D.J., et al., Proceedings of the Ocean Drilling Program, Initial Reports, 201: College Station, TX (Ocean Drilling Program), 1-103. http://dx.doi.org/10.2973/odp.proc.ir.201.105.2003

Yanagawa, K., Breuker, A., Schippers, A., Nishizawa, M., Ijiri, A., Hirai, M., Takaki, Y., Sunamura, M., Urabe, T., Nunoura, T., and Takai, K., 2014. Microbial community stratification controlled by the subseafloor fluid flow and geothermal gradient at the Iheya North Hydrothermal Field in the mid-Okinawa Trough (Integrated Ocean Drilling Program Expedition 331). Applied and Environmental Microbiology, 80(19):6126-6135. http:// dx.doi.org/10.1128/AEM.01741-14

Yanagawa, K., Nunoura, T., McAllister, S.M., Hirai, M., Breuker, A., Brandt, L., House, C.H., Moyer, C.L., Birrien, J.-L., Aoike, K., Sunamura, M., Urabe, T., Mottl, M.J., and Takai, K., 2013. The first microbiological contamination assessment by deep-sea drilling and coring by the D/V Chikyu at the Iheya North hydrothermal field in the Mid-Okinawa Trough (IODP Expedition 331). Frontiers in Microbiology, 4:327. http://dx.doi.org/ 10.3389/fmicb.2013.00327

Initial receipt: 20 November 2015

Acceptance: 26 August 2016

Publication: 4 October 2016

MS 331-203 
Table T1. Total (biological + chemical) and chemical activity in samples measured as heat output by microcalorimetry, Sites C0014, C0015, and C0017.

\begin{tabular}{|c|c|c|c|c|c|c|c|}
\hline \multirow[b]{2}{*}{ Hole } & \multirow[b]{2}{*}{$\begin{array}{l}\text { Depth } \\
\text { (mbsf) }\end{array}$} & \multicolumn{3}{|c|}{ Anaerobic } & \multicolumn{3}{|c|}{ Aerobic } \\
\hline & & $\begin{array}{l}\text { Total activity } \\
\text { at } 25^{\circ} \mathrm{C} \\
(\mu \mathrm{W} / \mathrm{g})\end{array}$ & $\begin{array}{l}\text { Total activity } \\
\text { at } 90^{\circ} \mathrm{C} \\
(\mu \mathrm{W} / \mathrm{g})\end{array}$ & $\begin{array}{c}\text { Chemical activity } \\
\text { at } 90^{\circ} \mathrm{C} \\
(\mu \mathrm{W} / \mathrm{g})\end{array}$ & $\begin{array}{l}\text { Total activity } \\
\text { at } 25^{\circ} \mathrm{C} \\
(\mu \mathrm{W} / \mathrm{g})\end{array}$ & $\begin{array}{c}\text { Total activity } \\
\text { at } 90^{\circ} \mathrm{C} \\
(\mu \mathrm{W} / \mathrm{g})\end{array}$ & $\begin{array}{c}\text { Chemical activity } \\
\text { at } 90^{\circ} \mathrm{C} \\
(\mu \mathrm{W} / \mathrm{g})\end{array}$ \\
\hline \multirow[t]{13}{*}{ C0014B } & 0.4 & 0 & 24 & 0 & 46 & 221 & 98 \\
\hline & 1.3 & 0 & 66 & 2 & 65 & 361 & 213 \\
\hline & 2.6 & 0 & 0 & 0 & ND & ND & ND \\
\hline & 4.0 & 0 & 32 & 12 & ND & ND & ND \\
\hline & 5.4 & 0 & 0 & 0 & ND & ND & ND \\
\hline & 6.5 & 0 & 0 & 0 & ND & ND & ND \\
\hline & 8.8 & 0 & 0 & 0 & ND & ND & ND \\
\hline & 15.3 & 0 & 0 & 0 & ND & ND & ND \\
\hline & 17.5 & 0 & 0 & 0 & ND & ND & ND \\
\hline & 20.0 & 0 & 87 & 0 & ND & ND & ND \\
\hline & 23.0 & 0 & 42 & 0 & ND & ND & ND \\
\hline & 24.9 & 0 & 0 & 0 & ND & ND & ND \\
\hline & 26.3 & 0 & 0 & 0 & ND & ND & ND \\
\hline \multirow[t]{9}{*}{ C0014D } & 0.3 & 0 & 0 & 0 & 67 & 158 & 0 \\
\hline & 2.1 & 0 & 0 & 64 & 59 & 362 & 482 \\
\hline & 3.2 & 0 & 0 & 0 & ND & ND & ND \\
\hline & 4.3 & 0 & 0 & 28 & ND & ND & ND \\
\hline & 6.7 & 0 & 18 & 0 & ND & ND & ND \\
\hline & 8.7 & 0 & 0 & 4 & ND & ND & ND \\
\hline & 10.2 & 0 & 0 & 92 & ND & ND & ND \\
\hline & 11.5 & 0 & 0 & 53 & ND & ND & ND \\
\hline & 12.9 & 0 & 0 & 123 & ND & ND & ND \\
\hline \multirow[t]{2}{*}{ C0015B } & 0.4 & 0 & 0 & 148 & 0 & 0 & 0 \\
\hline & 3.5 & 0 & 0 & 47 & 48 & 288 & 222 \\
\hline \multirow[t]{2}{*}{ C0015C } & 7.0 & 0 & 0 & 222 & 1 & 4 & 0 \\
\hline & 9.0 & 0 & 32 & 59 & 4 & 0 & 0 \\
\hline \multirow[t]{2}{*}{ C0017A } & 0.7 & 0 & 96 & 28 & 25 & 80 & 20 \\
\hline & 6.4 & 0 & 0 & 15 & 19 & 63 & 18 \\
\hline \multirow[t]{2}{*}{ C0017B } & 10.9 & 0 & 42 & 9 & 12 & 42 & 0 \\
\hline & 14.9 & 0 & 0 & 39 & 12 & 59 & 19 \\
\hline \multirow[t]{5}{*}{ C0017C } & 20.2 & 0 & 4 & 0 & 0 & 71 & 3 \\
\hline & 24.7 & 0 & 1 & 0 & 0 & 156 & 11 \\
\hline & 26.7 & 0 & 24 & 0 & 0 & 47 & 0 \\
\hline & 28.4 & 0 & 350 & 20 & 0 & 2 & 0 \\
\hline & 30.1 & 0 & 198 & 0 & 0 & 0 & 0 \\
\hline \multirow[t]{5}{*}{ C0017D } & 63.8 & 0 & 85 & 0 & 0 & 0 & 0 \\
\hline & 66.6 & 0 & 0 & 51 & 0 & 0 & 0 \\
\hline & 68.3 & 0 & 12 & 0 & 5 & 8 & 0 \\
\hline & 68.4 & 0 & 55 & 0 & 7 & 29 & 0 \\
\hline & 75.0 & 0 & 31 & 0 & 35 & 244 & 0 \\
\hline
\end{tabular}

$\mathrm{ND}=$ not determined

Table T2. Mean total (biological + chemical) and chemical activity in samples measured as heat output by microcalorimetry, Sites C0014, C0015, and C0017.

\begin{tabular}{lcccc}
\hline & $\begin{array}{c}\text { Total activity } \\
\text { at } 25^{\circ} \mathrm{C} \\
(\mu \mathrm{W} / \mathrm{g})\end{array}$ & $\begin{array}{c}\text { Total activity } \\
\text { at } 90^{\circ} \mathrm{C} \\
(\mu \mathrm{W} / \mathrm{g})\end{array}$ & $\begin{array}{c}\text { Chemical activity } \\
\text { at } 90^{\circ} \mathrm{C} \\
(\mu \mathrm{W} / \mathrm{g})\end{array}$ & $\begin{array}{c}\text { Number of samples } \\
\text { measured }\end{array}$ \\
\hline Anaerobic conditions & $<0.1$ & 30 & 25 & 40 \\
Aerobic conditions & 18 & 100 & 50 & 22 \\
\hline
\end{tabular}


Table T3. Overview of enrichment cultures and isolates at $12^{\circ} \mathrm{C}$, Sites C0013, C0014, and C0017.

\begin{tabular}{|c|c|c|c|c|c|c|c|c|c|c|c|}
\hline \multirow{2}{*}{\multicolumn{2}{|c|}{ Substrate in medium }} & \multicolumn{7}{|c|}{ Enrichments } & \multirow{2}{*}{\multicolumn{3}{|c|}{$\frac{\text { Number of isolates }}{\text { Aerobic }}$}} \\
\hline & & \multicolumn{2}{|c|}{ Anaerobic } & \multicolumn{2}{|c|}{ Aerobic } & \multicolumn{3}{|c|}{ Microaerophilic } & & & \\
\hline Hole, core, section & Depth (mbsf) & Monomer & Polymer & Monomer & Polymer & $\mathrm{Na}_{2} \mathrm{~S}$ & $\mathrm{Mn}(\mathrm{II})$ & $\mathrm{Fe}(\mathrm{II})$ & $\mathrm{Mn}(\mathrm{II})$ & Monomer & Polymer \\
\hline \multicolumn{12}{|l|}{$331-$} \\
\hline C0013E-1H-2 & 0.2 & & & $x$ & $x$ & $x$ & $x$ & $x$ & 1 & 3 & \\
\hline $\mathrm{C} 0013 \mathrm{~F}-1 \mathrm{H}-2$ & 0.3 & $\mathrm{x}$ & $\mathrm{x}$ & $\mathrm{x}$ & $\mathrm{x}$ & $\mathrm{x}$ & $\mathrm{x}$ & $\mathrm{x}$ & 10 & & 6 \\
\hline C0013D-1H-4 & 7.0 & $\mathrm{x}$ & $\mathrm{x}$ & $\mathrm{x}$ & $\mathrm{x}$ & & & & & & \\
\hline C0014B-2H-3 & 8.8 & $\mathrm{x}$ & $\mathrm{x}$ & $x$ & $\mathrm{x}$ & $x$ & $\mathrm{x}$ & & 11 & 1 & 6 \\
\hline C0014D-2H-3 & 10.2 & $\mathrm{x}$ & $\mathrm{x}$ & $\mathrm{x}$ & $\mathrm{x}$ & & & & & & \\
\hline C0014D-2H-4 & 11.5 & $\mathrm{x}$ & $\mathrm{x}$ & $\mathrm{x}$ & $\mathrm{x}$ & & $\mathrm{x}$ & & & 3 & 2 \\
\hline C0014D-2H-6 & 12.9 & $\mathrm{x}$ & $\mathrm{x}$ & $\mathrm{x}$ & $\mathrm{x}$ & & & & & & \\
\hline C0014B-2H-10 & 15.3 & & & $\mathrm{x}$ & $\mathrm{x}$ & & & & & & \\
\hline C0017A-1H-5 & 6.4 & $\mathrm{x}$ & $\mathrm{x}$ & $\mathrm{x}$ & $\mathrm{x}$ & $x$ & $\mathrm{x}$ & $\mathrm{x}$ & 2 & 6 & 6 \\
\hline C0017B-1H-2 & 10.9 & & & $\mathrm{x}$ & $x$ & $x$ & $x$ & $x$ & 2 & 3 & 4 \\
\hline C0017B-1H-5 & 14.9 & $\mathrm{x}$ & $\mathrm{x}$ & $\mathrm{x}$ & $\mathrm{x}$ & & $\mathrm{x}$ & & 1 & 4 & 7 \\
\hline $\mathrm{C} 0017 \mathrm{C}-2 \mathrm{H}-2$ & 30.1 & $\mathrm{x}$ & $\mathrm{x}$ & $\mathrm{x}$ & $\mathrm{x}$ & & $\mathrm{x}$ & & 1 & 6 & 12 \\
\hline C0017D-2H-5 & 75.0 & & & $\mathrm{x}$ & $\mathrm{x}$ & & $\mathrm{x}$ & & & 2 & 3 \\
\hline C0017D-7H-4 & 108.5 & $\mathrm{x}$ & $\mathrm{x}$ & $\mathrm{x}$ & $\mathrm{x}$ & & & & & & \\
\hline
\end{tabular}

$x=$ successful enrichment. 